\title{
In situ hybridisation of EBV DNA-DNA hybrids using wet heat in polypropylene containers
}

\author{
L G Labrecque
}

\begin{abstract}
Aims: To explore procedures designed to optimise DNA-DNA in situ hybridisation, using cells infected with Epstein-Barr virus (EBV) and tissues and subfragments of the EBV DNA as probes.

Methods: The denaturation step occurred in a polypropylene container, using wet heat generated by a hot water container, the pressure cooker, or the microwave oven, without coverslips, reaching a temperature of $121^{\circ} \mathrm{C}$ or more in these two last systems. Two different visualisation systems were used.

Results: Fixed cells and tumours harbouring a high and medium to low copy number (a few hundreds to 33 copies per cell), were clearly labelled, using a simple reiterated subfragment $(B a m W)$ of the EBV DNA, and fresh frozen cells, harbouring a very low copy number (one to two on average) labelled using $B a m W$ as well as BamH (single non-reiterated 6 kilobase subfragment).

Conclusion: This is a valuable alternative technique for DNA-DNA ISH that can be used in fresh frozen samples as well as fixed samples.
\end{abstract}

(F Clin Pathol 1992;45:1099-1104)

Since its first applications in $1969,{ }^{1-3}$ in situ hybridisation (ISH) has gained a progressively important place in science, initially in virology and pathology (endocrinology mainly), but now in a wide field of research and in some clinical laboratories. Its sensitivity and specificity, coupled with the more recent use of nonradioisotopic markers, ${ }^{45}$ have contributed to this increasing popularity. This technique remains problematic in that reproducibility can be unsatisfactory and it is quite labour intensive. Automation of ISH, or parts of it, should provide a solution in future. ${ }^{6-12}$ The denaturation step in ISH procedures, typically done by heating cells or tissue sections in a dry oven with a hybridisation mix placed between slide and coverslip, can present difficulties: heating on a hot plate can lead to an important loss in cell morphology; use of a coverslip sealed with rubber solution can lead to cell loss when removed. (The use of a siliconised or vinyl sheering coverslip or of a plastic autoclavable polypropylene bag can, however, reduce this risk.) Some studies (including one done in our laboratory) ${ }^{13-15}$ have shown that increasing the temperature produces a noticeable increase in sensitivity of DNA-DNA ISH, particularly on formalin fixed, paraffin wax embedded sections or when the copy number of the target DNA is low. In these cases a temperature more than $100^{\circ} \mathrm{C}$ seems optimal, but produces heat associated problems. In 1987 Coates et al used a microwave oven to accomplish the same effect as that obtained by high temperature ${ }^{14}$; this also increased the sensitivity of the ISH.

Now a technique has been devised that allows denaturation of the sample to a temperature of $100-121^{\circ} \mathrm{C}$ or greater without loss of morphology or cell number, and without material drying. A sealed coverslip is not required. The denaturation and hybridisation steps are carried out in polypropylene boxes used to store cytopathology slides. This technique can be used in a hot water container as well as in a microwave oven or pressure cooker. Cytospun and paraformaldehyde fixed cells, or formalin fixed, paraffin wax embedded cells, have been successfully analysed using this technique, assaying for the presence of Epstein-Barr virus (EBV) DNA using BamHI W (repetitive) and BamHI H (unique) subfragments of the genome.

\section{Methods}

EBV positive B cells, B95-8, Daudi, P3HRI, M81, Raji, AW Ramos, Namalwa, and EBV negative Ramos and SF9 cell lines (negative controls) were used. All cells grown in suspension, in supplemented RPMI 1640, were deposited by cytospinning on to slides (Shandon Cytospin 2), as described before. ${ }^{15}$ SF-9 (ovary cells from the night butterfly, spodoptera frugiperda) propagated in supplemented GRACE insect medium, ${ }^{16}$ were similarly deposited.

Cells spun at $200 \times g^{17}{ }^{18}$ for five minutes were washed twice in PBS (phosphate buffered saline) and fixed at a concentration of $10^{6}$ cells per $\mathrm{ml}$ in $10 \%$ formalin (three hours at $4^{\circ} \mathrm{C}$ ). They were spun again, then washed three times in PBS. The cell pellet was loosened with one to two drops of PBS and mixed with a $1 \%$ agar solution in $\mathrm{PBS}$ at $55^{\circ} \mathrm{C}$ in $100-200 \mu \mathrm{l}$ (enough to give a turbid clot). The mix was allowed to set, wrapped in cigarette paper, and soaked in $10 \%$ formalin for a minimum of two hours before being embedded in an automatic vacuum processor.

Sections were cut from the block at a thickness of $5 \mu \mathrm{m}$ and applied to poly-L-lysine coated slides, ${ }^{19}$ two sections per slide. Samples 
dried overnight in an oven at $37^{\circ} \mathrm{C}$ were stored in a dust free container at room temperature.

A nasopharyngeal carcinoma (NPC), isolated from a young Tunisian girl and propagated in nude mice, ${ }^{20}$ was used. Tumour biopsy specimens, frozen at $-70^{\circ} \mathrm{C}$, were cut with a cryostat into $5 \mu \mathrm{m}$ thick sections, applied, two sections per slide, on to polyL-lysine covered glass slides and stored at $-70^{\circ} \mathrm{C}$. Before use, they were thawed, fixed for 30 minutes in $4 \%$ paraformaldehyde, washed twice in PBS, and dehydrated in serially concentrated ethanol baths $(30 \%$, $60 \%, 80 \%, 95 \%$, absolute).

The tumour was put in $10 \%$ formalin overnight, then paraffin wax embedded in an automatic vacuum processor. Sections were cut to $5 \mu \mathrm{m}$ thickness, applied to poly-L-lysine covered slides, two per slide, and dried overnight at $37^{\circ} \mathrm{C}$.

Biotinylated probes of the B95-8 BamHI W EBV DNA subfragment ligated in pAT 153 vector and cloned in Escherichia coli, were biotinylated by nick translation (BRL) according to the manufacturer's instructions. The final concentration of DNA was adjusted to 20 $\mathrm{ng} / \mathrm{ml}$, in $10 \mathrm{mM}$ TRIS-HC1, $1 \mathrm{mM}$ EDTA (pH 8). The BamHI W subfragment, 3.1 kilobases in length, is represented a variable number of times in the viral genome (overall target length 10-40 kilobases). Namalwa cells were hybridised with a cloned BamHI H subfragment, which is present as a unique 6.0 kilobase fragment in the viral DNA.

\section{HYBRIDISATION PROTOCOL}

Prehybridisation (Adapted from Brigati et $a l^{21}$ and from Hopman et al). ${ }^{22}$ Briefly, cytospun cells were treated in $0.02 \mathrm{M} \mathrm{HCl}$, washed in PBS, then treated in $0.01 \%$ Triton $X-100$. Resulting material was washed in PBS, digested with Pronase in TRIS-HC1 $0.05 \mathrm{M}$ and EDTA $5 \mathrm{mM}$, pH 7.6 (at a concentration of 0.1 to $0.25 \mathrm{mg} / \mathrm{ml}$ for three to six minutes, according to the cell line), washed in PBSglycine $2 \mathrm{mg} / \mathrm{ml}$, incubated with RNAse A 100 $\mathrm{mg} / \mathrm{ml}$ for one hour at $37^{\circ} \mathrm{C}$, washed in PBS and PBS glycine, dehydrated in ethanol baths $(30 \%, 60 \%, 80 \%, 95 \%$, absolute) and air dried.

The fresh frozen $\mathrm{C} 15$ tumour was treated in the same manner, but after the last wash in PBS glycine it was immersed in $3 \% \mathrm{H}_{2} \mathrm{O}_{2}$ in methanol for 30 minutes (to remove endogenous peroxidase activity if horseradish peroxidase was used), washed in $\mathrm{H}_{2} \mathrm{O}$, and dehydrated in ethanol baths, as above.

Formalin fixed, paraffin wax embedded cells were dewaxed in xylene, washed in absolute ethanol, and air dried. They were digested with $4 \mathrm{mg} / \mathrm{ml}$ pepsin in $\mathrm{HCl} 0.01 \mathrm{M}$ at $37^{\circ} \mathrm{C}$ for 60 minutes, then washed with $\mathrm{H}_{2} \mathrm{O}$, digested with RNAse A for one hour at $37^{\circ} \mathrm{C}$, washed in PBS, dehydrated in ethanol baths as above, and air dried.

Paraffin wax embedded, formalin fixed $\mathrm{C} 15$ tumour sections were immersed in $3 \% \mathrm{H}_{2} \mathrm{O}_{2}$ in methanol for 30 minutes after the absolute ethanol wash, then washed in $\mathrm{H}_{2} \mathrm{O}$, digested in pepsin- $\mathrm{HCl}$ for 60 minutes at $37^{\circ} \mathrm{C}$, washed in
$\mathrm{H}_{2} \mathrm{O}$, dehydrated in ethanol baths and air dried.

\section{Hybridisation}

The mix, freshly prepared, was made up of $50 \%$ formamide (stock solution kept at $-70^{\circ} \mathrm{C}$, in small aliquots, after deionisation on Amberlite monobed resin MB-3 (BDH Chemicals, Poole, UK), $2 \times$ SSC $(20 \times$ stock is $3 \mathrm{M}$ $\mathrm{NaCl} / 330 \mathrm{mM}$ sodium citrate), $2 \times$ Denhardt's solution $\left(50 \times\right.$ stock, kept at $-20^{\circ} \mathrm{C}$, is $1 \%$ polyvinylpyrrolidone, $1 \%$ Ficoll, and $1 \%$ bovine serum albumin, $250 \mu \mathrm{g} / \mathrm{ml}$ calf thymus DNA) $2.5 \mathrm{mM}$ sodium phosphate $10 \%$ (w/v), dextran sulfate $(50 \%$ freshly prepared stock before adding to the mix), and biotinylated DNA probe (used at a concentration of $0 \cdot 2-0 \cdot 4 \mu \mathrm{g} / \mathrm{ml}$ ). A separate control mix was prepared with biotinylated vector (that is, without EBV DNA) only.

A ring was drawn around the cells or tissue with rubber solution, the latter allowed to dry, and $8 \mu \mathrm{l}-12 \mu \mathrm{l}$ of mix was added to each sample; slides were introduced carefully into a polypropylene box (Histo-Lab, Hertz, England) below a "blank" slide, placed on the top row to collect the water condensation. No coverslip was added (but one can be added, if desired, without rubber solution). The lid was closed and denaturation was carried out according to one of three following protocols: (1) The covered box was put on a rack in a container of boiling water for five to 10 minutes (SSC could be added to increase the temperature), then removed, and put on ice to cool. (The rate of cooling does not seem to influence the result of ISH). Hybridisation was then carried out in a water bath at $37^{\circ} \mathrm{C}$ overnight.

(2) The box was put on a tray in a pressure cooker containing boiling water, and pressure applied with a light $\left(5 \mathrm{lbs} \rightarrow 108^{\circ}\right)$ or heavy (15 lbs $\rightarrow 121^{\circ}$ ) weight, and left for two to six minutes. The pressure cooker was cooled quickly under cold tap water, then the box removed, and manipulated as in (1).

(3) Water (125-150 ml) in a large Petri dish, was brought to the boil in a microwave oven. A plastic container and the polypropylene box were put in this, the lid of the Petri dish (pressing on the top of the plastic container) was replaced, and the microwave (Toshiba, model ER-644) put on at cook ( $1 \frac{1}{2}$ to $2 \frac{1}{2}$ minutes) and reheat (3-4 minutes) settings. Hybridisation was then carried out as described above.

After hybridisation, the rubber solution was removed and the slides were washed for 10 minutes with agitation (magnetic stirrer) in 2 $\times$ SSC three times at room temperature, and for 30 minutes in $0.1 \times S S C$ at $42^{\circ} \mathrm{C}$.

\section{Cytochemical visualisation}

Two detection procedures were used: streptavidin alkaline phosphatase (SAP) (Bluegene, BRL (A)), and indirect immunoperoxidase (B).

The SAP technique was used in accordance with the manufacturer's instructions. Slides were first soaked for 10 minutes in a blocking 


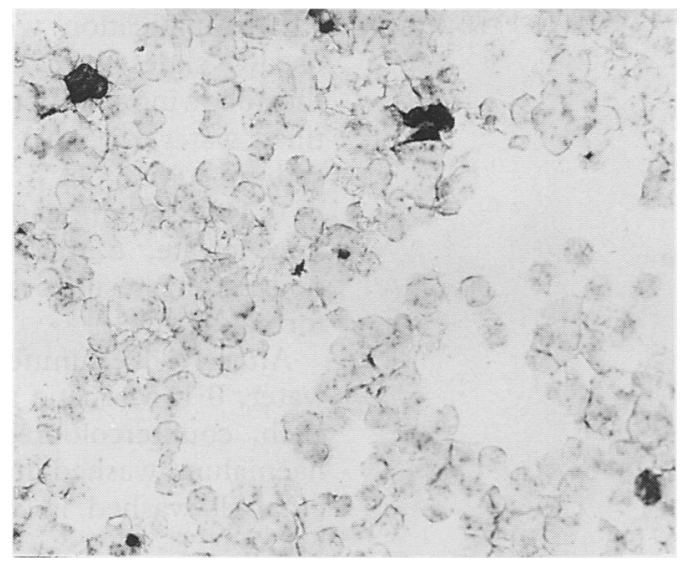

Figure $1 A$ B95-8 cells (cytospun). Heavy labelling is observed in a small proportion of the cells; most of the others show a fine, particulate pattern (alkaline phosphatase).

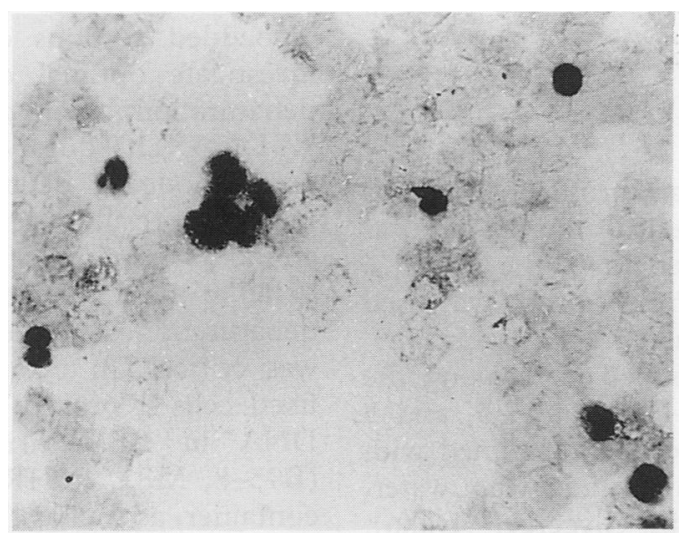

Figure 1B B95-8 cells (cytospun). Results with a preparation kept at room temperature for a period of more than two years, showing heavy labelling, typical of the producer cell lines and a lighter pattern in many other cells (alkaline phosphatase).

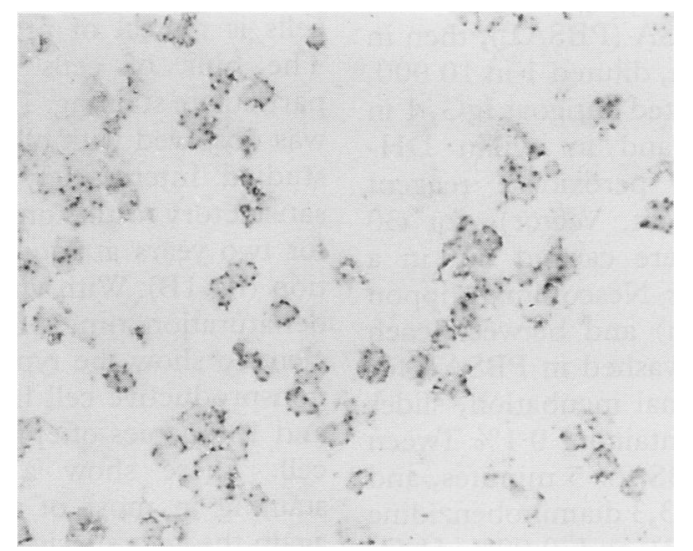

Figure 1C Raji cells (cytospun). Cells show a particulate pattern with some variation of density and intensity (alkaline phosphatase).

buffer (buffer 2), composed of $3 \%$ bovine serum albumin (BSA) fraction $\mathrm{V}$, in buffer 1 : $0 \cdot 1 \mathrm{M}$ TRIS- $\mathrm{HCl}, \mathrm{pH} 7 \cdot 5$, and $0 \cdot 15 \mathrm{M} \mathrm{NaCl}$. The excess liquid was removed and the SAP mix $(2 \mu \mathrm{g} / \mathrm{ml})$ in incubating buffer $(0 \cdot 1 \mathrm{M}$ TRIS-HCl $+0 \cdot 15 \mathrm{M} \mathrm{NaCl}$ ) applied for 10 minutes. The slides were then washed for 10 minutes in buffer 1 , and for 10 minutes in developing buffer (buffer 3: $0 \cdot 1 \mathrm{M}$ TRIS- $\mathrm{HCl}$, pH $9.5,0.1 \mathrm{M} \mathrm{NaCl}, 0.05 \mathrm{M} \mathrm{MgCl}_{2}$ ); the excess liquid was removed and the developing mix, consisting of NBT (nitroblue tetrazolium) $330 \mathrm{mg} / \mathrm{ml}$ and DPIC (5-Bromo-4-chloro-
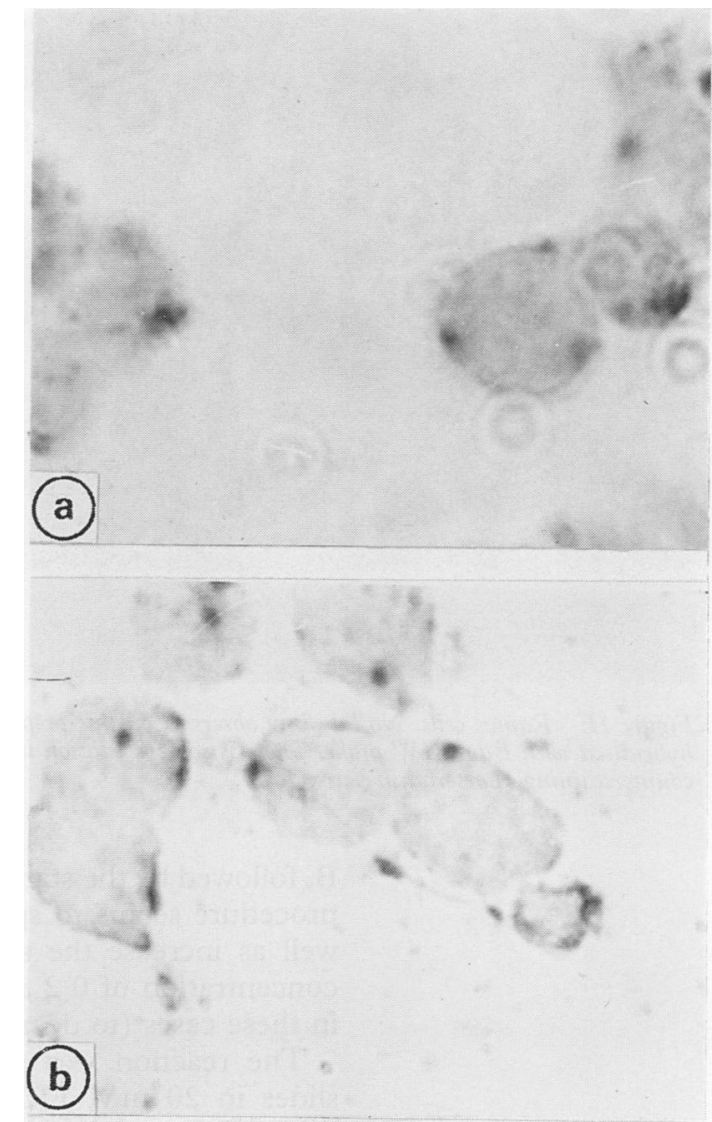

(c)

Figure 1D Ramos cells. No labelling observed on this preparation (negative control), hybridised with BamHI W probe. (a) Namalwa cells, hybridised with BamHIH probe. (b) Same cells, hybridised with BamHIW probe. Most of the signals are on the nuclear margin of the cells, clearly different from the signal we would expect to see if the nucleolus was shown up by the technique. (c) Namalwa cells, hybridised with biotinylated vector only. No signal is evident. In these three cases visualisation was performed using the direct PA technique; it was allowed to develop overnight.

3-indoyl-phosphate) $170 \mathrm{mg} / \mathrm{ml}$ in buffer 3 , was applied to the cells. Development was carried out in the dark, for a period varying from one to four hours or more. The sensitivity of visualisation of the very low copy number can be increased by a longer incubation (even overnight), but this can increase the background. The speed of visualisation appears to be quite variable, and the best way is to monitor it at regular intervals. Care has to be taken to avoid drying of the slides. An indirect technique can be applied (goat antibiotin antiserum, and biotinylated anti-goat IgG as in 


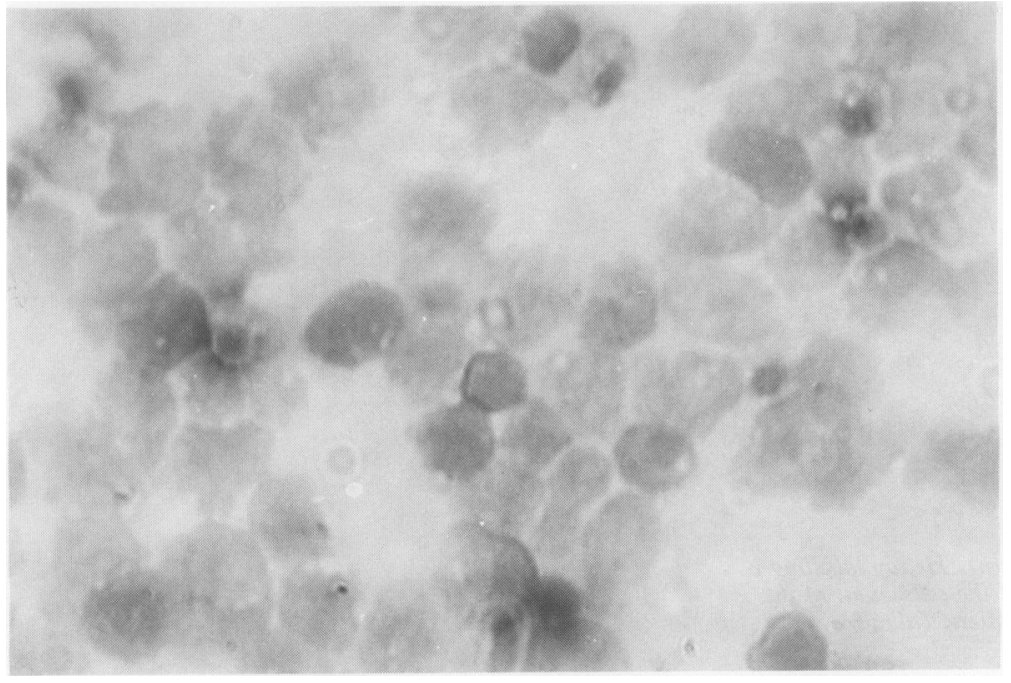

Figure 1E Ramos cells. No labelling observed on this preparation (negative control), hybridised with BamHIW probe. There is some variation in the intensity of counterstaining (horseradish peroxidase).
If amplification with silver and gold was used, ${ }^{18}$ slides were incubated sequentially in the following solutions (after washing in distilled water): $2.5 \mathrm{mM}$ gold choride; $0.1 \mathrm{mM}$ sodium sulfite, $\mathrm{pH} 7 \cdot 5^{23}$; developer, composed of $0.24 \mathrm{M}$ sodium carbonate, $13 \mathrm{mM}$ ammonium nitrate, $6 \mathrm{mM}$ silver nitrate, $1.5 \mathrm{mM}$ dodecatungstosilicic acid and $0.6 \mu \mathrm{l} / \mathrm{ml} 40 \%$ formaldehyde.

After 10-15 minutes, slides were washed in water, $0 \cdot 17 \mathrm{M}$ acetic acid (twice), 15 minutes each, countercoloured with haematoxylin or haemalum, washed in tap water, dehydrated in ethanol, washed in xylene, and mounted in DPX.

\section{Results}

Initially, cytospun cells and paraffin wax embedded sections of pellets were used to investigate optimal conditions for substrate denaturation, before detection of EBV BamHI W DNA. The question was whether the unusual mode of denaturation would lead to improved results (sensitivity and specificity) and allow a full preservation of morphological detail at the temperatures needed for efficient denaturation, and whether the use of coverslips was critical. In cytospun, paraformaldehyde fixed cells it proved possible to visualise the DNA in EBV virus-producing cell lines (B95-8, M81, P3HR-1) using the hot water container, as well as the pressure cooker (used mainly with the light weight, reaching a temperature of $108^{\circ} \mathrm{C}$ ), and either the alkaline phosphatase or horseradish peroxidase detection system. Figure 1A shows B95-8 cells, using the first of these. Heavy labelling in a few cells is typical of productively infected cells. The bulk of cells show a more discrete, particulate staining. The same labelling pattern was observed with all the productive cell lines studied. Interestingly, the same protocols gave satisfactory results on slides that had been kept for two years at room temperature after fixation (fig 1B). With virus producer cell lines, a denaturation time of five minutes was sufficient to show the typical heavy labelling. Raji non-productive cell lines harbour between 50 and 100 copies of episomal EBV genomes per cell. These show a particulate pattern of staining in most of the cells (fig 1C). Here again the cells survived temperatures of $100^{\circ} \mathrm{C}$ or greater for 10 minutes. In Namalwa and AW Ramos cell lines, which contain an average of one to two copies per cell, most of the cells show very low density labelling (fig $1 \mathrm{D}(\mathrm{a})$ ), but in this case, a unique subfragment $(B a m \mathrm{HI} \mathrm{H})$, 6 kilobases in size was used as probe. BamW was used successfully as well (fig $1 \mathrm{D}(\mathrm{b})$ ). Thus, in spite of a small target, it was possible to visualise the EBV genome in cells that have a very low copy number. The cells hybridised with the biotinylated vector (fig $1 \mathrm{D}(\mathrm{c})$ ) did not show any clinically important labelling, after the same incubation time in the substrate, allowing a noticeable difference between the probe and the vector slides to be demonstrated, and showing that the labelling is not due to non-specific revelation of the nucleolus. A 
Figure $3 A \quad B 95-8$ (formalin fixed, paraffin wax embedded). A heavy pattern of labelling is seen in many cells, with a sparse pattern in others (alkaline phosphatase).

Figure 3B Raji (formalin fixed, paraffin wax embedded). Most of the cells present a particulate labelling with a discrete, minimal background observed horseradish peroxidase, with silver-gold amplification).

Figure 3C C15 tumour (formalin fixed, paraffin wax embedded).

Microwaved, irradiated.

Labelling, inside the

nuclear boundaries, can be seen in numerous cells present in this preparation (alkaline phosphatase).

Figure 3D C15 tumour (formalin fixed, paraffin wax embedded) using biotinylated vector only, where there is no evident labelling (alkaline phosphatase).

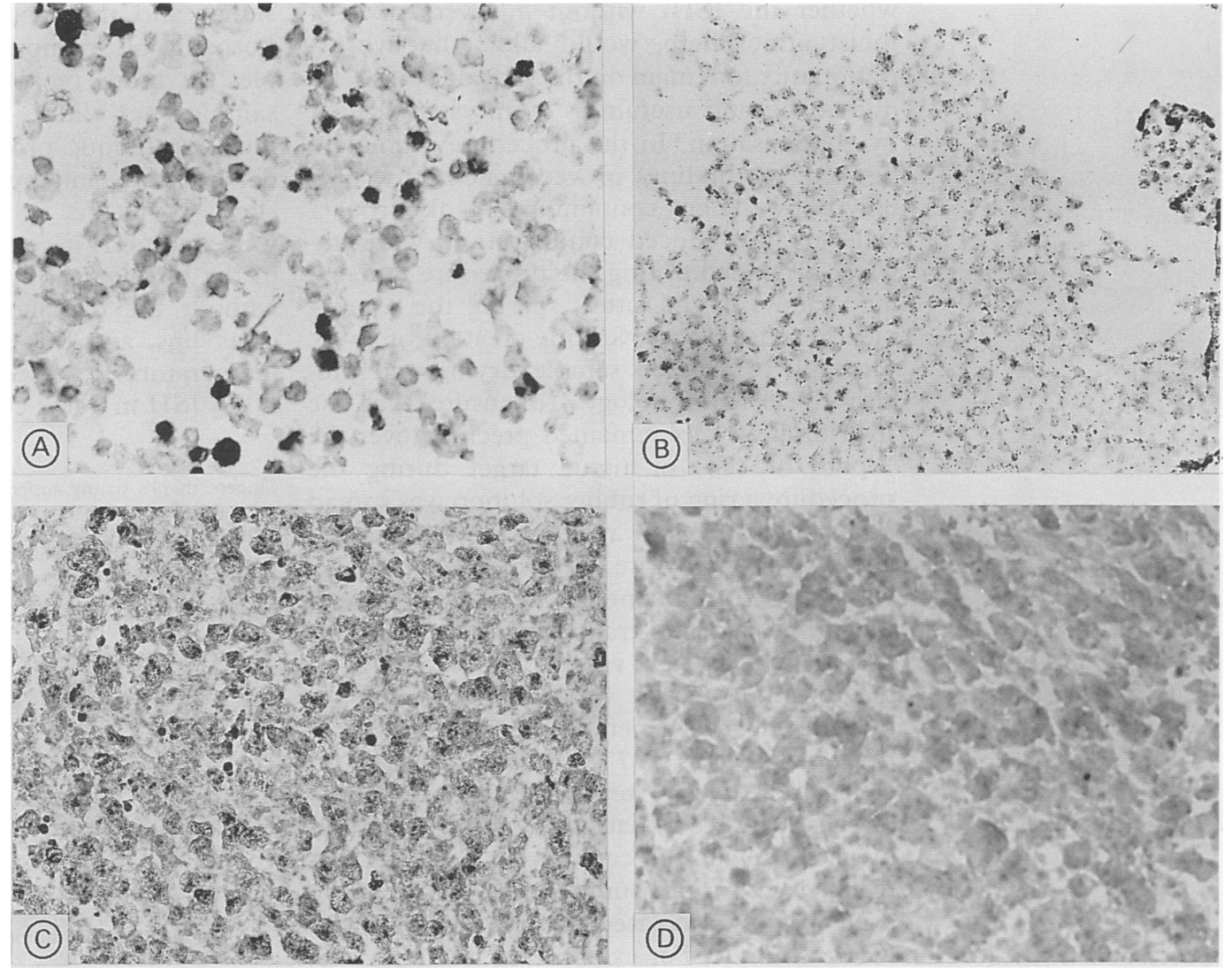

concentration of probe at $0.4 \mu \mathrm{g} / \mathrm{ml}$ gave good results, without relevant background, as well as a concentration of $0.2 \mu \mathrm{g} / \mathrm{ml}$, revealed by the indirect SAP technique with the hybridisation carried out in a hot water container, as well as in the pressure cooker. Two cell lines (Ramos, a lymphoid cell line derived from an EBV negative Burkitt's lymphoma and SF-9, an insect cell line) were used as negative controls. Neither showed clinically important labelling when hybridised with $\mathrm{BamHI}$ W probe (fig 1E).

The C15 NPC tumour was used as a model for tissue harbouring only episomal EBV DNA (in this case 30 copies per cell). Freshly frozen, paraformaldehyde fixed, biopsy specimens showed a particulate pattern of staining with BamHI W, confined to the nucleus of cells (fig 2). A tissue sample hybridised with the biotinylated vector only (data not given), showed no evidence of hybridisation.

A second set of experiments involved using formalin fixed, paraffin wax embedded cells. In such processed samples, cross- linking between molecules decreased the efficacy of DNADNA hybridisation by blocking hybridisation sites on the target DNA, a problem that could partly be overcome by increased denaturation temperatures. B95-8, P3HR1, M81 and Daudi cell lines did not really present a detection difficulty, due to the high copy number of EBV DNA (averaging several hundred per cell line) and the ability of some cells to produce virus, giving dense staining. For such cells, a denaturation temperature of $100^{\circ} \mathrm{C}$, applied for five to 10 minutes, permitted the identification of many heavily labelled cells (fig 3A); in addition (data not shown), formalin fixed paraffin embedded samples survived high temperature very well, that is, $127^{\circ} \mathrm{C}$ reached in the pressure cooker (heavy weight) and $132-138^{\circ} \mathrm{C}$ in the microwave oven (using thermal recording strips). Furthermore, Raji (a non-producer line) showed particulate staining in most cells, with minimal background, when treated for six to eight minutes in the pressure cooker or in the microwave oven (fig 3B). However, if denaturation was carried out in a hot water container for five minutes, or in the pressure cooker at full temperature (light weight) for two to three minutes only, no signals were observed. Finally, paraffin wax embedded C15 tumour samples were submitted to the same procedure. Tumour tissue denatured at $100^{\circ} \mathrm{C}$ was negative, but a clear particulate pattern was observed when the microwave procedure was used (fig 3C). Experiments using vector only were negative (fig 3D), as were formalin fixed, paraffin wax embedded Namalwa cells, where no significant differences were seen between samples hybridised with the EBV probe or with vector alone.

\section{Discussion}

The usual procedure for denaturation of DNA prior to DNA-DNA hybridisation experiments is to heat cells or tissue, placed between a slide and coverslip, together with a hybridisation mix, in a dry oven or a hot plate. In my experience this process frequently leads to loss of cells and altered morphology of survivors, making interpretation of the results of the ISH difficult, if not impossible. Wet heat has sometimes been used in microwave irradiation of material, ${ }^{14}{ }^{15}$ as well as in a recently described automised ISH machine ${ }^{12}$ where the slides, incubated upside down, were exposed to a hybridisation mix by positive pressure from a peristaltic pump and by capillary action. I examined the feasibility of using wet heat, without a coverslip, in a widely available polypropylene container. It had not been clear 
whether the ISH, without a coverslip, in a moist atmosphere, would allow the hybridisation mix to remain on the slide and, if so, be diluted beyond usefulness with water formed by condensation. In the procedure ultimately devised, my findings proved that the use of a polypropylene box containing a blank ("roof") slide greatly reduced condensation, with any water produced during the procedure remaining mainly on the latter, sparing the experimental slides. Moreover, the creation of a wet atmosphere avoided sample drying and preserved cell morphology. To ensure that the hybridisation mix remained precisely over the "spot" of cells or tissue target during the procedure a ring of rubber solution was spread a few millimetres away from the sample and allowed to dry before applying the mix. This was sufficient to maintain the contact between the probe and substrate; an atmosphere saturated with water vapour permitted good preservation of cells. Cytospin paraformaldehyde fixed cells generally tolerated temperatures as great as $127^{\circ} \mathrm{C}$ and over. Using no coverslip avoided a step that can lead to a loss of cells (a process that can also be minimised by use of siliconised coverslips). The high heat reached with a pressure cooker or microwave oven notably increased the sensitivity of the ISH technique. For example, in boiling water, paraffin wax embedded, EBV positive Raji cells gave a negative result, whereas a clear signal, without loss of cell morphology was observed when the cells were submitted to a higher temperature. The polypropylene boxes adopted for these purposes melt at $167^{\circ} \mathrm{C}$, and although they "soften" at lower temperatures $\left(100^{\circ} \mathrm{C}\right)$, this has presented no problems. Boxes have been reused several dozen times with no trouble.

Unlike the procedures that necessitate the complete coverage of slides with hybridisation mixes, ${ }^{712}$ this technique uses a very small amount of mix (and probe) in each sample, allowing considerable economy of reagents. Moreover, various hybridisations can be carried out on the same slide using different probes, provided that samples are separated by rubber solution to avoid any possible mixing of reagents. In contrast to earlier experiments, ${ }^{15}$ the streptavidin-alkaline phosphatase procedure, using a kit with improved sensitivity (Blue Gene, Bethesda Research Laboratories) allowed as little as $0.25 \mathrm{pg}$ of target DNA to be detected. With the very low copy number cells (Namalwa and A-W Ramos), the use of a probe at a concentration of $0.4 \mu \mathrm{g} / \mathrm{ml}$ (or 0.2 $\mu \mathrm{g} / \mathrm{ml}$ if indirect SAP technique was used), gave good results, even with a single 6 kilobase probe. The visualisation step has to be monitored, however, particularly with the indirect technique, to avoid background staining. If a large tumour section was analysed and the quantity of probe used increased to cover it, acceleration of the heating process sometimes caused a drying of the mix after exposure in the microwave oven. In such cases the exposure time was reduced (a calibration before use is recommended, or a coverslip is added) to avoid this problem: the pressure cooker does not present this difficulty. In the protocol developed each box permits the processing of four slides, and three boxes per experiment can normally be manipulated, analysing 12 samples or more (according to the number of samples per slide). The polypropylene container technique provides good conditions of denaturation and hybridisation for ISH in a simple, versatile, and economical way. In the wet conditions it generates, good preservation of the histological morphology is maintained, without the damages sometimes created by coverslips, and this in spite of the very high temperature required for optimising DNADNA ISH in a low copy number gene setting.

Sincere thanks to my supervisor, Professor BE Griffin, for a critical review of the manuscript and to Ms Elizabeth Bashford for typing the manuscript. LGL is supported by the Medical Research Council of Canada and acknowledges gratefully a grant from the QCCH Special Health Authority for this project.

1 Buongiorno-Nardelli M, Amaldi F. Autoradiographic detecion of molecular hybrids between rRNA and DNA tissue sections. Nature 1969;225:946-7.

2 Gall G, Pardue ML. Formation and detection of RNA DNA hybrid molecules in cytological preparations. Proc Natl Acad Sci USA 1969;63:378-81.

3 John HI, Birnstiel ML, Jones KW. RNA-DNA hybrids at the cytological level. Nature 1969;223:582.

4 Manuelides L, Langer-Safer PR, Ward DC. High resolution mapping of satellite DNA using biotin-labelled DNA probes. I Cell Biol 1982;95:619- 25

5 Morris RG, Arends MJ, Bishop PE, Sizer K, Duvall E, Bird CC. Sensitivity of digoxigenin and biotin labelled probes for detection of human papillomavirus by ISH. 7 Clin Pathol 1990;43:800-5.

6 Unger ER, Brigati DJ, Chenggis ML, Budgeon LR, Koeble $D$, Cuomo C, Kennedy T. Automation of in situ hybridization: Application of the capillary action workstation. F Histotechnol 1988;11:253-58.

7 Brigati DJ, Budgeon LR, Unger ER, Koebler D, Cuomo C, Kennedy T, Perdomo JM. Immunocytochemistry is autoKennedy T, Perdomo JM. Immunocytochemistry is autothe capillary action principle. $f$ Histotechnol 1988 ; the capillary

8 Stark E, Faltinat D, Van der Fecht R. An automated device for immunocytochemistry. F Immunol Methods 1988 107:89-92.

9 Stross WP, Jones M, Mason DY. Automation of APAAP immunocytochemical technique. F Clin Pathol 1985 42:106-12.

10 MaWhinney WHB, Warford A, Rae MJL, Lauder I. Automated immunochemistry. F Pathol 1989;157:168A

11 MaWhinney WHB, Warford A, Rae MJL, Lauder I. Automated immunochemistry. $\mathcal{F}$ Clin Pathol 1990;43:591-6.

12 Takahashi $T$, Ishiguro $\mathrm{K}$. Development of an automatic machine for in situ hybridization and immunohistochem istry. Analyt Biochem 1991;196:390-402.

13 Unger ER, Budgeon LR, Myersan D, Brigati DJ. Vira diagnosis by ISH. Description of a rapid simplified colorimetric method. Am $\mathcal{F}$ Surg Pathol 1986;10:1 - 8

14 Coates PJ, Hall PA, Butler MG, D'Ardenne AJ. Rapid technique of DNA-DNA ISH on formalin fixed tissue sections using microwave irradiation. $f$ Clin Pathol 1987;40:865-9.

15 Teo CG, Griffin BE. Visualisation of single copies of the EBV genome by ISH. Analyt Biochem 1990;186:78-85.

16 Summers MD, Gale ES. A manual of methods for baculovirus vectors and insect cell culture procedures. Texas Agricultural Experiment Station Bulletin 1988; 1555:38-42.

17 Harlow E, Lane D. Antibodies. A laboratory manual. Cold Spring Harbor: Cold Spring Harbor Laboratory, 1988.

18 Burns J, Chan VTW, Jonasson JA, Fleming KA, Taylor S, McGee JO'D. Sensitive system for visualising biotinylated DNA probes hybridised in situ: rapid sex determination of intact cells. $\mathcal{F}$ Clin Pathol 1985;38:1085- 92

19 Huang WM, Gibson SJ, Facer P, Gu J, Polak JM. Improved section adhesion for immunocytochemistry using high molecular weight polymers of L-Lysine as a slide coating. Histochemistry 1983;77:275-9.

20 Hitt MM, Allday M, Hara T, Karran L, Jones M, Busson P, Tursz T, Ermberg I, Griffin B. EBV gene expression in an NPC- related tumour. $E M B O \mathcal{F}$ 1989;8:2639-51.

21 Brigati DT, Myerson D, Leary JJ, Spalholz B, Travis SZ, Fong CKY, Hsiung GD, Ward DC. Detection of viral Fong CKY, Hsiung GD, Ward DC. Detection of vira genomes in cultured cells and parafne embedded tissue Sections using biotin-labe

22 Hopman AHN, Ramaekers FCS, Vooijs GP. Interphase cytogenetics of solid tumours. In: Polak JM, McGee cytogenetics of solid tumours. In: Polak JM, McGee JO'D, eds. In situ hybridization principles and pra
Oxford: Oxford Science Publications, 1990:170-2.

23 Cremers AFM, Jansen in de Wal N, Wiegant J, Dirks RW, Weisbeek P, van der Ploeg M, Landegent JE. Nonradioactive ISH - a comparison of several immunocytochemical detection systems using reflection-contras and electron microscopy. Histochemistry 1987;86 $609-15$ 